\title{
Assessment of the Antimicrobial and Fertilizing Activity of Table Olive Concentrated Waste Streams During Their Shelf Life
}

\author{
Manuel Brenes $^{1} \cdot$ Berta De Los Santos $^{2} \cdot$ Ana Aguado $^{2} \cdot$ Antonio De Castro $^{1} \cdot$ Pedro García $^{1} \cdot$ Concepción Romero $^{1}$ (I)
}

Received: 1 July 2021 / Accepted: 2 December 2021 / Published online: 22 December 2021

(c) The Author(s) 2021

\begin{abstract}
Table olive wastewaters represent a big problem for factories not yet solved. Some partial solutions are the purification, the reuse or the generation of a smaller volume of these liquids. The purpose of this study was to investigate the possibility of obtaining a concentrate that can be stable over time and that has a biofertilizing capacity on tomato (Solanum lycopersicum L.) plants. In this study, washing waters from Spanish style green and storage liquids from black ripe olive processing were vacuum concentrated up to 10,13 and 17 times so that they reached total sugar content of up to $700 \mathrm{mmol} \mathrm{L}^{-1}, 925 \mathrm{mmol}$ $\mathrm{L}^{-1}$ and $1200 \mathrm{mmol} \mathrm{L}^{-1}$ respectively. Interestingly, the evaporation achieved to retain most of the phenolic compounds that ranged from $18 \mathrm{mmol} \mathrm{L}^{-1}$ in the fresh solution to $140 \mathrm{mmol} \mathrm{L}^{-1}$ in the solution concentrated 10 times. Moreover, these concentrates showed in vitro antimicrobial activity against the bacteria Erwinia amylovora and Pseudomonas syringae, and the Oomycota Phytophthora sp. In addition, they increased the strength and cumulative yield of the tomato plants cultivated under greenhouse conditions, even after 12 months of storage at room temperature. It has been demonstrated that it is possible to reduce the large volume of the wastewaters of the table olive industry, and the concentrates have potential application for agricultural uses, even after 1 year of storage, thereby contributing to a more environmentally sustainable industry.
\end{abstract}

\section{Graphical Abstract}

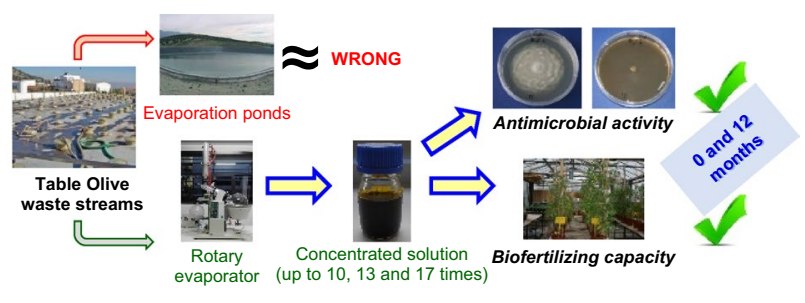

Keywords Olives (Olea europaea L.) · Washing water · Tomato (Solanum lycopersicum L.) · Antifungal · Biofertilizer

\section{Statement of Novelty}

Olives are one of the most economically important food products in Mediterranean countries and table olive factories are interested in finding an alternative to the large amount

Concepción Romero

c.romero@csic.es

1 Food Biotechnology Department, Instituto de la Grasa (IGCSIC), Ctra. de Utrera, Km. 1, Building 46, 41013 Seville, Spain

2 Centro IFAPA Las Torres (CAPDER - JA). Apartado de Correos Oficial, 41200 Alcalá del Rio, Seville, Spain of wastewater they generate. This manuscript demonstrates the feasibility of the vacuum evaporation technique applied to table olive wastewaters which is a solution that could be used as a biofertilizer in agriculture and, in addition, exerts antimicrobial activity against plant pathogenic microorganisms. This article presents the novelty that these concentrates are chemically and microbiologically stable and equally effective after 12 months, being an alternative as an agricultural fertilizer. The philosophy of this manuscript is in agreement with the concepts of circular economy and waste valorization. Hence, we consider that the results presented in 
this manuscript are of great importance for scientists, table olives processors and society in general.

\section{Introduction}

The table olive industry is of great importance in the fermented vegetable world economy. The average production of this foodstuff during the last 5 years has approximately been of 2,805,000 tons, Spain accounting for at least 20\% of the total. However, the big problem that threatens this very productive food field is the high volume of wastewaters that it produces. Until now, the research on this issue has been focused on the purification treatment of these wastes, their reuse in the factories to minimize the volume generated, or on finding compounds of biological interest.

Although there are many methods to elaborate edible olives, the Spanish style green and the Californian-black olives are the two most commercially important, particularly in Spain. Both methods lead to alkaline waste streams (spent lyes and washing waters) plus fermentation brines.

Ozonization [1, 2], electrocoagulation [3] and electrochemical treatments $[4,5]$ could, to a large extent, reduce the chemical oxygen demand contamination of the table olive wastewaters. Aerobic and anaerobic treatments alone, or in combination with another technique, have also been researched with promising results for the organic contamination reduction in these $[6,7]$.

The reuse of these solutions in other stages of the olive processing has also been studied [8-10], as well as new methods to obtain compounds of biological interest for the food and pharmaceutical industries [11-13].

However, none of these technologies have been implemented at the industrial scale. Moreover, researchers have found antibacterial and antifungal activity in several olive processing wastewaters [11, 14-16]; and recently, it has been demonstrated that these wastes can be used as bio-stimulants in tomato cultivation [17]. Additionally, some solutions free of sodium chloride from the table olive industry have demonstrated having a bio-fertilizing effect on some Mediterranean crops $[18,19]$. The substitution of sodium hydroxide by potassium hydroxide for the same agronomic purpose has also been proposed [19, 20].

Table olives are a seasonal product, and their wastewaters are produced during a specific period of time, which does not coincide with tomato and pepper crops. For this reason, the technique of vacuum evaporation of said liquids has been considered in order to obtain concentrates that were easy to handle [20], which would have the benefit of reducing the volume of these wastewaters, and allow availability of these bio-fertilizing solutions throughout the year.

The aims of this work were (i) to chemically characterize the concentrates obtained from table olive waste solutions, (ii) to demonstrate their chemical and microbiological stability over time, (iii) to confirm their bio-fertilizing use, and (iv) their antimicrobial activity with concentrates stored for a year.

\section{Materials and Methods}

\section{Table Olive Solutions}

\section{Two Experiments were Designed}

Assay 1: eight samples of Spanish style green olive washing waters of the processing of 'Hojiblanca' cultivar and four acid storage liquids samples of the black ripe olive processing were obtained from olive factories located in Seville (Spain). The storage liquids had been in contact with olives of the 'Hojiblanca' cultivar for 6 months under aerobic conditions. These liquids had $12 \mathrm{~g} \mathrm{~L}^{-1}$ of acetic acid, and a $\mathrm{pH}$ around 4.0 units.

Subsequently, solutions were concentrated 10 times under vacuum, and their $\mathrm{pH}$ was adjusted to 5.0 units. The alkaline $\mathrm{pH}$ of the concentrated washing waters was dropped with $60 \%$ nitric acid, and the $\mathrm{pH}$ of the preservation solutions was raised with $6 \mathrm{~mol} \mathrm{~L}^{-1}$ potassium hydroxide. In addition, nonconcentrated fresh washing waters were acidified with nitric acid $(\mathrm{pH}<3.0)$ to prevent undesirable fermentations. Both non-concentrated and concentrated solutions were stored for 9 months at room temperature.

Assay 2: two samples of Spanish style green olive washing waters of the processing of 'Hojiblanca' and 'Manzanilla' cultivars were obtained from local factories (Seville, Spain). They were concentrated up to 10,13 and 17 times in a vacuum. Then, the $\mathrm{pH}$ of the concentrates was adjusted to 5.0 units with $6 \mathrm{~mol} \mathrm{~L}^{-1}$ potassium hydroxide. All solutions were stored at room temperature for 12 months.

\section{Chemical Analyses of the Table Olive Solutions}

Solutions were filtered through a $0.22-\mu \mathrm{m}$ pore size nylon filter, and organic acids and ethanol were analyzed by HPLC [18]. Sugars and phenolic compounds were analyzed in the filtered solutions by HPLC as described elsewhere [21].

Carbon and nitrogen were analyzed by elemental analysis using a LECO CHNS-932 analyzer (St Joseph, MI, USA). Previously, the samples were dried at $105^{\circ} \mathrm{C}$ and their moisture was calculated.

Sodium and potassium concentrations were determined by flame photometry [18]. $1 \mathrm{~g}$ of liquid was digested by a DigiPREP equipment (Quebec, Canada) with $25 \mathrm{~mL}$ of $14 \mathrm{~mol} \mathrm{~L}^{-1}$ nitric acid at $120^{\circ} \mathrm{C}$ for $8 \mathrm{~h}$.

Calcium, iron, magnesium, copper, manganese and zinc were determined by atomic absorption [20] in a GBC 
model 932 AA (Victoria, Australia) atomic absorption spectrometer.

The analysis of phosphorus was carried out using the colorimetric method proposed elsewhere [22]. Measurements were taken in a Cary UV/Visible spectrophotometer model 60 (Agilent Technologies, Ca, USA) at $420 \mathrm{~nm}$.

The density of the liquids was measured at $20{ }^{\circ} \mathrm{C}$ with a $0.1 \mathrm{~L}$ volumetric flask, and the viscosity analyzed with a viscometer Ostwald at $20{ }^{\circ} \mathrm{C}$.

\section{Bactericidal Activity}

The solutions of Assay 1 were tested at time 0 and after 9 months. All concentrates were diluted to their original volume with autoclaved tap water before evaluating their bactericidal activity. Washing waters were tested at 100 and $50 \%$ of their original concentrations, and the storage liquids of black ripe olives at $2 \%$ and $5 \%$ of their original concentrations. The $\mathrm{pH}$ of all solutions was adjusted to 5.5 with potassium hydroxide, and they were filtered through $0.22 \mu \mathrm{m}$ before inoculation. Two controls with just tap water at $\mathrm{pH}$ 5.5, and $1.2 \%$ acetic acid in tap water at $\mathrm{pH} 5.5$ were also carried out. $150 \mu \mathrm{L}$ of the olive or control solutions were inoculated with $10 \mu \mathrm{L}$ of an overnight culture of E. amylovora and $P$. syringae diluted with saline, to obtain an initial population ca. $10^{7} \mathrm{CFU} / \mathrm{mL}$. The mixture was incubated at room temperature for $5 \mathrm{~min}$ with occasional shaking, and then plated onto nutrient agar to count survivors after up to 5 days of incubation at $30^{\circ} \mathrm{C}$. The percentage of inhibition was equals to the difference of the initial population (\%) minus the surviving population after incubation (\%) in each assay.

\section{Activity Against Fungi and Oomycota}

The solutions of Assay 1 and 2 were tested at time 0 and after 9 or 12 months of storage. The phytophatogenic activity was carried out against Fusarium solani, Phytophthrora sp., Botrytis cinerea and Macrophomina phaseolina. All concentrates were diluted to their original volume before evaluating their phytophatogenic activity.

Fungi and Phytophthrora sp. were grown on potato dextrose agar (PDA) from Difco Laboratories (Detroit, MI) at $25^{\circ} \mathrm{C}$ for 7 days. PDA $(20 \mathrm{~mL})$ prepared with different percentages of olive solutions to achieve different concentrations $(10 \%, 25 \%, 50 \%)$, and was poured into sterilized petri dishes. A mycelial disc (5 mm diameter) was taken from the periphery of an actively growing PDA culture, and placed at the center of an $85 \times 13 \mathrm{~mm}$ petri dish. The dishes were incubated at $25^{\circ} \mathrm{C}$. The control treatment consisted of a petri dish with the mycelial disc, but PDA was diluted with sterile distilled water or $1.2 \%$ acetic acid in distilled sterile water.
After 3-6 days of incubation, the diameter of the colonies was recorded.

Phytopathogenic toxicity was expressed in terms of percentage of mycelial growth inhibition (MGI, \%), and calculated following the formula as described elsewhere [23]:

$\% \mathrm{MGI}=\mathrm{dc}-\mathrm{dt} / \mathrm{dc}$

where dc is the average diameter of phytopathogens colony in the control, and dt is the average diameter of phytopathogens colony in the treatment. For each treatment, each compound, and each of the tested doses, three replicate petri dishes were used.

\section{Agronomic Experimental Design}

Two pot trials were performed in a greenhouse as described elsewhere [24].

Tomato (cv. 'Optima') plants were transplanted in midDecember 2015 (Trial 1) and in mid-December 2016 (Trial 2). Two washing waters from Spanish style green olive processing were tested, from the 'Hojiblanca' and 'Manzanilla' cultivars. Wastewater solutions (Assay 2) were concentrated up to 10 times and diluted to the original volume to test them. In Trial 1 the solutions tested were freshly concentrated and in Trial 2 the solutions tested were the same but after 12 months of storage of the concentrates at pH 5.0. Also, two control solutions were used, tap water and a solution of potassium nitrate $\left(7.81 \mathrm{~g} \mathrm{~L}^{-1}\right.$ of potassium and $2.80 \mathrm{~g}$ $\mathrm{L}^{-1}$ of nitrogen). The solutions tested and potassium nitrate liquid were diluted 1:4 (20\%) and 1:1 (50\%) with tap water, and were irrigated three times on a bi-weekly basis, the first time 15 days post-transplant. Throughout the two trials, irrigation was carried out in a conventional manner with tap water. The tomato plants were kept in the greenhouse for 6 months.

\section{Morphological Analyses of Tomato Plants}

Plant height $(\mathrm{cm})$ was measured weekly throughout four and 2 months in Trial 1 and 2, respectively. The progress in flowering and the number of open flowers per plant were observed and recorded once a week until fruiting [25]. The progress in flowering was expressed as the percentage of plants that showed at least one open flower.

\section{Tomato Fruits Production Analyses}

Tomatoes were harvested during the final months of the assay, and the parameters measured were medium number of fruits per plant, cumulative yield $\left(\mathrm{g}_{\text {plant }}{ }^{-1}\right)$ and fruit medium weight $\left(\mathrm{g}\right.$ fruit $\left.{ }^{-1}\right)$. 


\section{Tomato Fruits Quality Analyses}

Fruit medium caliber $(\mathrm{cm})$ and firmness (shore) were evaluated. The $\mathrm{pH}$, sweetness ( ${ }^{\circ}$ Brix), acidity (\% of citric acid) and maturity index (sweetness/acidity) were evaluated in the tomato puree $(100 \mathrm{~g})$. The data of these parameters was the average of ten or seven harvestings of tomato fruits in Trial 1 and 2 , respectively.

\section{Statistical Analysis}

Chemical data was the mean of replicates \pm standard deviation. The pot experiments were performed using a completely randomized design and results were expressed as the mean of six replications \pm standard error. One-way ANOVA were applied to determine the significant differences among treatments. All means were compared according to the least significance differences (LSD) test at 5\% significance level. All statistical analyses were performed with Statistix 9.0 (Analytical Software, Ltd., La Jolla, CA, USA).

\section{Results and Discussion}

\section{Chemical Characterization of Waste Solutions from the Table Olive Industry}

The concentration of acetic acid and ethanol was minimal in the washing waters and much higher in the storage liquids (Table 1); which was expected due to the initial addition of the organic acid in the latter case, and yeast fermentation during the storage period. The main sugars detected in the non-concentrated washing waters were glucose and mannitol, with an average value of total sugars of $73.2 \pm 16.5 \mathrm{mmol}$ $\mathrm{L}^{-1}$ and $80.4 \pm 13.8 \mathrm{mmol} \mathrm{L}^{-1}$ at time 0 and after 9 months preservation, respectively. Likewise, the concentration of phenolic compounds was relevant, highlighting hydroxytyrosol as the major compound, something already found in several olive waste streams by other researchers [4, 26], followed by tyrosol. The presence of the dialdehydic form of decarboxymethyl elenolic acid linked to hydroxytyrosol (HyEDA) in storage liquids, whose antimicrobial activity has been widely demonstrated [21], must be noted. Other phenolic compounds were detected at a lower concentration and the sum of all of them represented a concentration in the range of $1.5 \pm 0.7 \mathrm{mmol} \mathrm{L}^{-1}$ and $3.6 \pm 1.0 \mathrm{mmol}$ $\mathrm{L}^{-1}$ in non-concentrated washing waters and storage liquids respectively. Thus, the mean value of total phenols in the
Table 1 Chemical characterization of nonconcentrated and concentrated table olive solutions

\begin{tabular}{|c|c|c|c|c|}
\hline \multirow[t]{2}{*}{ Compounds } & \multicolumn{2}{|l|}{ Washing water } & \multicolumn{2}{|l|}{ Storage liquid } \\
\hline & Non-concentrated & Concentrated $^{\mathrm{a}}$ & Non-concentrated & Concentrated \\
\hline Acetic acid $\left(\%, \mathrm{w} \mathrm{v}^{-1}\right)$ & $0.06 \pm 0.02$ & $0.06 \pm 0.03$ & $0.83 \pm 0.18$ & $1.59 \pm 0.19$ \\
\hline Ethanol $\left(\%, \mathrm{w} \mathrm{v}^{-1}\right)$ & $0.02 \pm 0.01$ & nd & $0.56 \pm 0.30$ & nd \\
\hline Sucrose $\left(\mathrm{mmol} \mathrm{L}^{-1}\right)$ & $0.4 \pm 0.2$ & nd & $1.0 \pm 0.2$ & $7.7 \pm 1.7$ \\
\hline Glucose $\left(\mathrm{mmol} \mathrm{L}^{-1}\right)$ & $34.6 \pm 10.5$ & $306.8 \pm 138.9$ & $15.4 \pm 6.1$ & $110.0 \pm 39.7$ \\
\hline Fructose $\left(\mathrm{mmol} \mathrm{L}^{-1}\right)$ & $12.6 \pm 2.2$ & $116.8 \pm 51.8$ & $3.6 \pm 0.9$ & $36.1 \pm 4.1$ \\
\hline Mannitol $\left(\mathrm{mmol} \mathrm{L}^{-1}\right)$ & $25.8 \pm 5.5$ & $158.9 \pm 75.0$ & $45.7 \pm 9.0$ & $369.5 \pm 62.7$ \\
\hline Hydroxytyrosol $\left(\mathrm{mmol} \mathrm{L}^{-1}\right)$ & $11.0 \pm 3.0$ & $61.1 \pm 15.1$ & $6.3 \pm 0.8$ & $71.9 \pm 14.2$ \\
\hline Tyrosol $\left(\mathrm{mmol} \mathrm{L}^{-1}\right)$ & $1.3 \pm 0.3$ & $12.1 \pm 2.0$ & $0.1 \pm 0.0$ & $6.8 \pm 1.3$ \\
\hline $\operatorname{HyEDA}^{\mathrm{b}}\left(\mathrm{mmol} \mathrm{L}^{-1}\right)$ & nd & nd & $1.1 \pm 0.7$ & $7.5 \pm 5.1$ \\
\hline Carbon $\left(\%, \mathrm{w} \mathrm{w}^{-1}\right)$ & $1.54 \pm 0.31$ & $12.78 \pm 2.25$ & $1.83 \pm 0.41$ & $12.82 \pm 2.45$ \\
\hline Nitrogen $\left(\%, \mathrm{w} \mathrm{w}^{-1}\right)$ & $0.38 \pm 0.15$ & $3.03 \pm 1.15$ & $0.04 \pm 0.01$ & $0.28 \pm 0.05$ \\
\hline Sodium $\left(\mathrm{g} \mathrm{L}^{-1}\right)$ & $4.45 \pm 2.21$ & $28.29 \pm 15.69$ & $0.39 \pm 0.01$ & $3.59 \pm 0.28$ \\
\hline Potassium $\left(\mathrm{g} \mathrm{L}^{-1}\right)$ & $1.20 \pm 0.24$ & $7.54 \pm 1.85$ & $2.32 \pm 0.12$ & $17.49 \pm 1.91$ \\
\hline Calcium $\left(\mathrm{g} \mathrm{L}^{-1}\right)$ & $0.04 \pm 0.02$ & $0.60 \pm 0.37$ & $0.21 \pm 0.01$ & $1.84 \pm 0.14$ \\
\hline Other minerals ${ }^{\mathrm{c}}\left(\mathrm{g} \mathrm{L}^{-1}\right)$ & $0.09 \pm 0.02$ & $0.75 \pm 0.18$ & $0.09 \pm 0.01$ & $0.83 \pm 0.05$ \\
\hline
\end{tabular}

Eight washing waters from Green-Spanish olive and four storage liquids from black ripe olive processes were analyzed. Values are mean \pm standard deviation

${ }^{\mathrm{a}}$ Ten times concentration

${ }^{b}$ HyEDA: dialdehydic form of decarboxymethyl elenolic acid linked to hydroxytyrosol

${ }^{c}$ Other minerals are the sum of iron, magnesium, copper, manganese, zinc and phosphorous. nd, not detected 
non-concentrated washing waters was $20.0 \pm 11.5 \mathrm{mmol}$ $\mathrm{L}^{-1}$ and $19.3 \pm 5.4 \mathrm{mmol} \mathrm{L}^{-1}$ at time 0 and after 9 months preservation, respectively, which coincides with previous data [26].

Other components of interest found in these solutions were minerals including carbon, nitrogen, sodium, potassium and calcium; which could be involved in the biofortifying effect observed in Mediterranean crops irrigated with these table olive solutions [18, 24]. Besides, they possess COD values around $40-45 \mathrm{~g} \mathrm{~L}^{-1}$, density $1.15 \mathrm{~g} \mathrm{~mL}^{-1}$, and total solids $290 \mathrm{~g} \mathrm{~kg}^{-1}$ [20] thereby they are heavy contaminated liquids as it also happens with the olive mill wastewaters that have COD of $80 \mathrm{~g} \mathrm{~L}^{-1}, \mathrm{BOD}_{5}$ of $18.72 \mathrm{~g} \mathrm{~L}^{-1}$, dry matter of $135.7 \mathrm{~g} \mathrm{~L}^{-1}$ and volatile matter of $58.7 \mathrm{~g} \mathrm{~L}^{-1}$ [27].

As mentioned above, from a practical point of view, they must be concentrated before their use in agriculture. This technique allows the removal of some volatile contaminants, reduces the final volume of the waste and increases the stability of these solutions.

Hence, their concentration of up to 10 times under vacuum was studied, yielding very interesting results (Table 1). In relation to the volatile compounds, acetic acid did not change or scarcely increased in the preservation liquid concentrate, and ethanol disappeared in both concentrates. Conversely, sugars, phenolic compounds and minerals remained to a large extent, reaching a concentration of 6-10 times higher than the source solution. It is worth noting that the

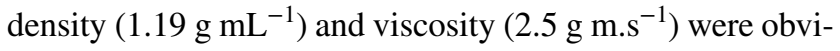
ously higher than those of the non-concentrated solutions, yet they had adequate handling fluidity. Moreover, the dark color of the concentrate suggested the occurrence of several chemical reactions during evaporation, such as the polymerization and Maillard type as reported elsewhere [28]. This could explain why our concentrates did not have the expected composition of sugars, phenols and minerals; some of these individual compounds were polymerized.

Similarly, it was found that all these solutions remained chemically stable after 9 months of storage at room temperature without any visual microbial growth, even at $\mathrm{pH} 5.0$ in the concentrates. The value of total sugars was $667.4 \pm 122.4$ and $565.1 \pm 94.4$ at time 0 and after 9 months preservation, respectively. Likewise, the value of total phenols was $121.3 \pm 20.2$ and $133.1 \pm 24.0$ at time 0 and after 9 months preservation, respectively.

\section{Assessment of the Antimicrobial Activity of Waste Solutions from the Table Olive Industry}

The antimicrobial activity at 0 months of the non-concentrated solutions from industrial table olive wastewaters were tested against the phytopathogenic bacteria $E$. amylovora and $P$. syringae, and no viable cells of both microorganisms were detected in any of the assays (data not shown), similar with results previously found [14]. All solutions contained a significant concentration of hydroxytyrosol (Table 1), whose antibacterial capacity has already been demonstrated by other authors [11, 15], this activity was greater when storage liquids were tested as a result of the additional presence of HyEDA (Table 1).

Likewise, the antimicrobial character of these non-concentrated solutions was evaluated against the pathogenic Oomycota Phytophthora sp., and $100 \%$ growth inhibition was found for all solutions tested, either diluted or undiluted (data not shown). Similar results have been attributed to hydroxytyrosolrich olive mill wastewater, which had shown a powerful antimicrobial activity against phytopathogens [16].

In addition, results depicted in Fig. 1 confirmed that the vacuum concentration of these solutions did not eliminate their antimicrobial activity. No viable cells of E. amylovora were recovered after $5 \mathrm{~min}$ contact with the washing waters (Fig. 1a). Similar results were found for $P$. syringae with all solutions. Again, better results were achieved with storage solutions of the black ripe olive processing (Fig. 1b), as loss of viability was found at concentrations as low as $2-5 \%$.

In the case of the table olive concentrates against non-bacterial pathogens, the in vitro assays were carried out with $M$. phaseolina, B. cinerea, F. solani and Phytophthora sp. All concentrates exerted a $100 \%$ inhibition against the 4 phytopathogens if they were used undiluted, decreasing this effect when increasing dilution. In particular, concentrates from washing waters diluted to 10,25 and $50 \%$ of the initial volume did not show any effect against the first three fungi, and only presented growth inhibition against Phytophthora sp. (Fig. 1c). In contrast, the concentrates of storage liquids inhibited the growth of the four microorganisms, even applied at $10 \%$ dilution, as for example 40-50\% growth inhibition for M. phaseolina, $B$. cinerea and $F$. solani, and even more active against Phytophthora sp. (Fig. 1c).

Additionally, all these concentrated solutions were stored at room temperature for 9 months and their antimicrobial activity tested again. In comparison with results obtained at time 0 of storage, the antibacterial activity of the washing waters decreased against E. amylovora and increased against P. syringae (Fig. 2a), although a great variability was found. In contrast, the antibacterial activity of the concentrates of storage liquids increased with time (Fig. 2b). Regarding activity against Phytophthora sp., all concentrates increased this property with storage time (Fig. 2c). 

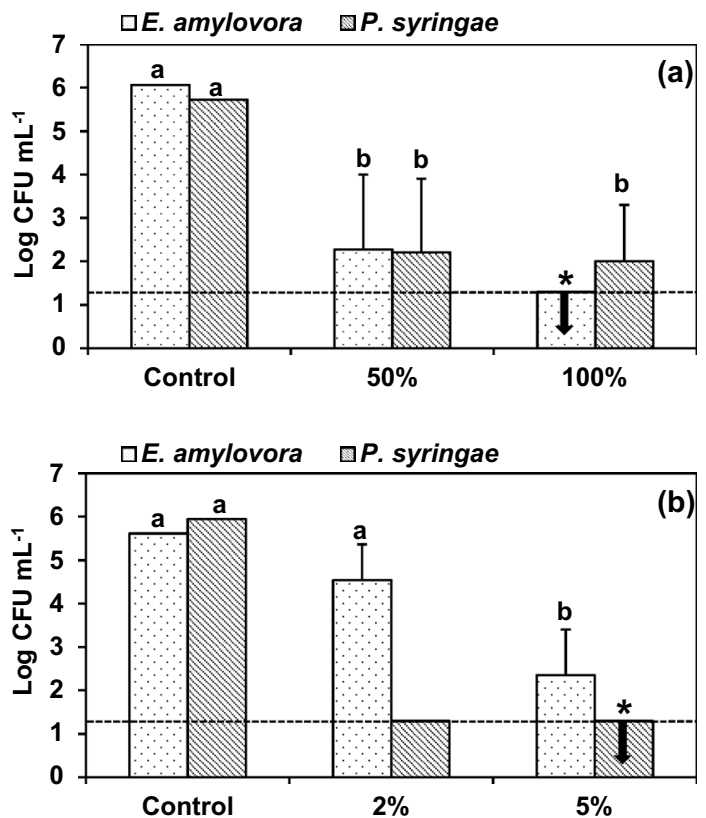

$\square W W C \triangle S L C$

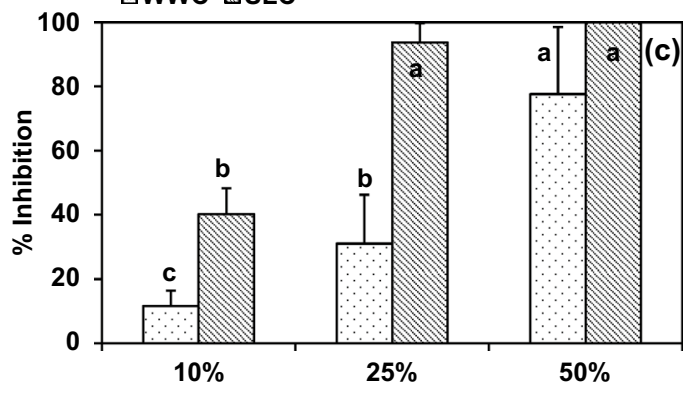

Concentration of solution tested

Fig. 1 Bactericidal effect of washing water (a) and storage liquid (b) concentrates against E. amylovora and $P$. syringae at different $\%$ from their original concentration. Mycelial growth inhibition of Phytophthora sp. (c) in washing water (WWC) and storage liquid (SLC) concentrates. Standard deviation of eight and four replicates respectively is depicted in each bar. Bars of the same micro-organism (a and b) or the same solution tested (c) followed by the different letters, indicate significant differences according to the LSD test $(p<0.05)$. *Under detection limit (1.3 Log CFU mL $\left.\mathrm{mL}^{-1}\right)$

\section{Influence of the Degree of Concentration in the Chemical Composition and Antimicrobial Activity of Concentrates Obtained from Waste Solutions of the Table Olive Industry. Stability Over Time}

Concentration of the waste solutions is a key factor for their commercialization, so a higher concentration than 10 times was tested (Assay 2). Washing waters were concentrated up to 13 and 17 times, the density and viscosity of the concentrates being $1.26 \mathrm{~g} \mathrm{~mL}^{-1}$ and $1.38 \mathrm{~g} \mathrm{~mL}^{-1}$, and $3.89 \mathrm{~g} \mathrm{~m}^{-1}$ $\mathrm{s}^{-1}$ and $9.81 \mathrm{~g} \mathrm{~m} \mathrm{~s}^{-1}$ respectively. All this data indicated that concentrates up to 17 times could be handled, although
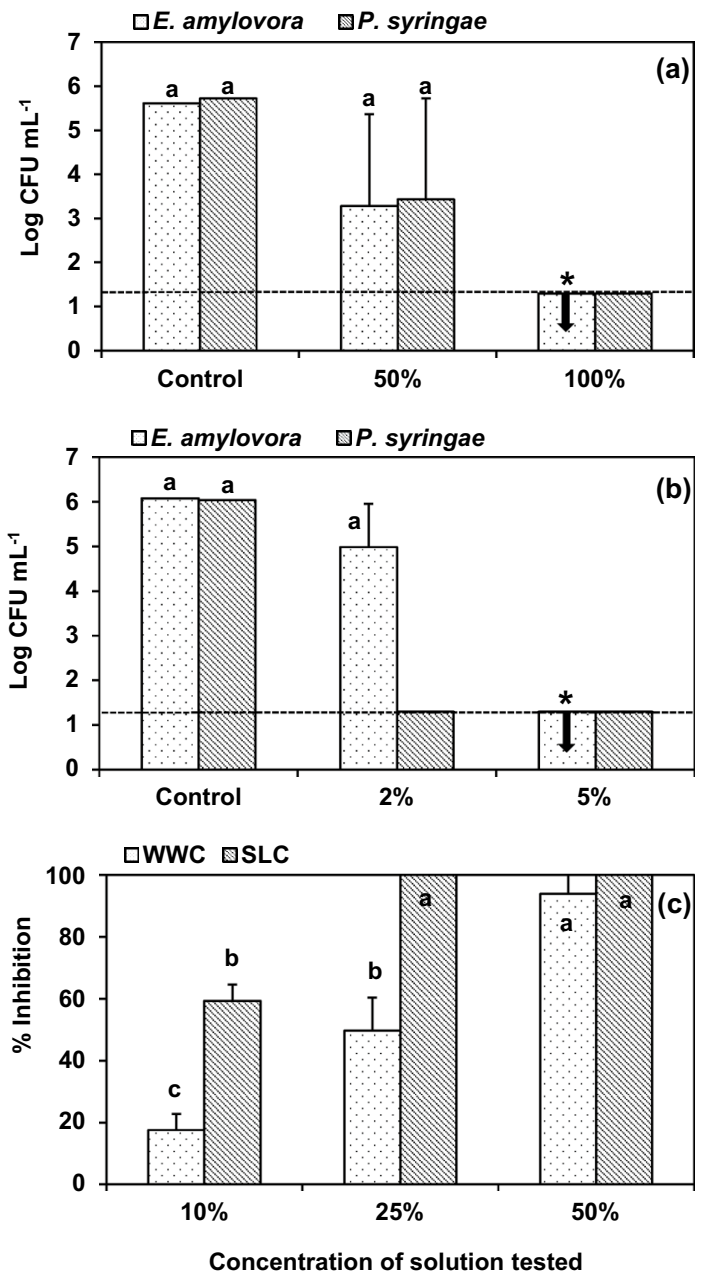

Fig. 2 Bactericidal effect of washing water (a) and storage liquid (b) concentrates against $E$. amylovora and $P$. syringae after 9 months of storage at room temperature. Mycelial growth inhibition of Phytophthora sp. (c) by washing water (WWC) and storage liquid (SLC) concentrates after 9 months of storage at room temperature. Standard deviation of eight and four replicates respectively is depicted in each bar. Bars of the same microorganism (a and $\mathbf{b}$ ) or the same solution tested (c) followed by the different letters indicate significant differences according to the LSD test $(p<0.05)$. ${ }^{*}$ Under detection limit (1.3 Log CFU mL ${ }^{-1}$ )

their stability and antimicrobial activity with time ought to be tested.

Table 2 shows the results of total and individual sugars and phenols concentration of the freshly prepared concentrated solutions $(0 \mathrm{~m})$, stored for 12 months at room temperature $(12 \mathrm{~m})$. With respect to total sugars, an increase of these substances can be seen with the degree of concentration at time 0 , which was observed for each of the individual sugars analyzed. On the contrary, total phenols tended to decrease with the intensity of the concentration, particularly in the concentrates of the Manzanilla cultivar. The oxidation rate of $o$-diphenols such as hydroxytyrosol at $\mathrm{pH} 5$ should be low, but vacuum evaporation was carried out at $60^{\circ} \mathrm{C}$. Most 
Table 2 Sugars (glucose, fructose, mannitol and total) and phenols (hydroxytyrosol, hydroxytyrosol-1-glucose, tyrosol and total) concentrations of the washing water concentrated at different degrees (10, 13 and 17 times)

\begin{tabular}{|c|c|c|c|c|c|c|c|}
\hline \multirow[t]{2}{*}{ Compound $\left(\mathrm{mmol} \mathrm{L}^{-1}\right)$} & \multirow{2}{*}{$\begin{array}{l}\text { Time } \\
\text { (months) }\end{array}$} & \multicolumn{3}{|c|}{ 'Manzanilla' cultivar } & \multicolumn{3}{|c|}{ 'Hojiblanca' cultivar } \\
\hline & & 10 & 13 & 17 & 10 & 13 & 17 \\
\hline \multirow[t]{2}{*}{ Glucose } & 0 & $444.2 \pm 4.2 \mathrm{Ca}^{\mathrm{a}}$ & $566.1 \pm 11.3 \mathrm{Ba}$ & $871.0 \pm 18.2 \mathrm{Aa}$ & $293.8 \pm 5.7 \mathrm{Ca}$ & $406.1 \pm 16.2 \mathrm{Ba}$ & $516.1 \pm 39.1 \mathrm{Aa}$ \\
\hline & 12 & $478.2 \pm 8.8 \mathrm{Ca}$ & $537.8 \pm 1.5 \mathrm{Ba}$ & $758.7 \pm 3.9 \mathrm{Aa}$ & $342.6 \pm 24.2 \mathrm{Ca}$ & $390.0 \pm 22.1 \mathrm{Ba}$ & $533.3 \pm 13.9 \mathrm{Aa}$ \\
\hline \multirow[t]{2}{*}{ Fructose } & 0 & $169.9 \pm 2.3 \mathrm{Ca}$ & $218.1 \pm 3.5 \mathrm{Ba}$ & $333.3 \pm 7.4 \mathrm{Aa}$ & $100.0 \pm 2.8 \mathrm{Ca}$ & $135.2 \pm 7.6 \mathrm{Ba}$ & $174.7 \pm 10.7 \mathrm{Aa}$ \\
\hline & 12 & $177.8 \pm 4.4 \mathrm{Ca}$ & $201.7 \pm 1.6 \mathrm{Bb}$ & $281.1 \pm 8.3 \mathrm{Ab}$ & $112.4 \pm 6.8 \mathrm{Ca}$ & $129.0 \pm 8.4 \mathrm{Ba}$ & $176.7 \pm 2.7 \mathrm{Aa}$ \\
\hline \multirow[t]{2}{*}{ Mannitol } & 0 & $98.6 \pm 8.9 \mathrm{Ca}$ & $124.8 \pm 8.5 \mathrm{Ba}$ & $183.8 \pm 7.3 \mathrm{Aa}$ & $271.4 \pm 4.2 \mathrm{Cb}$ & $353.7 \pm 11.9 \mathrm{Ba}$ & $394.5 \pm 35.2 \mathrm{Ab}$ \\
\hline & 12 & $106.4 \pm 8.7 \mathrm{Ca}$ & $119.9 \pm 1.9 \mathrm{Ba}$ & $167.1 \pm 4.1 \mathrm{Aa}$ & $327.0 \pm 22.3 \mathrm{Ca}$ & $364.5 \pm 23.4 \mathrm{Ba}$ & $504.1 \pm 7.3 \mathrm{Aa}$ \\
\hline \multirow[t]{2}{*}{ Total Sugars } & 0 & $716.1 \pm 2.1 \mathrm{Ca}$ & $913.3 \pm 22.7 \mathrm{Ba}$ & $1393.4 \pm 34.3 \mathrm{Aa}$ & $677.0 \pm 12.5 \mathrm{Ca}$ & $897.5 \pm 35.1 \mathrm{Ba}$ & $1088.3 \pm 85.6 \mathrm{Aa}$ \\
\hline & 12 & $765.6 \pm 22.0 \mathrm{Ca}$ & $862.4 \pm 2.1 \mathrm{Ba}$ & $1213.0 \pm 15.3 \mathrm{Ab}$ & $785.1 \pm 53.1 \mathrm{Ca}$ & $885.9 \pm 54.5 \mathrm{Ba}$ & $1216.8 \pm 24.9 \mathrm{Aa}$ \\
\hline \multirow[t]{2}{*}{ Hydroxytyrosol } & 0 & $221.7 \pm 3.1 \mathrm{Aa}$ & $186.6 \pm 4.1 \mathrm{Ca}$ & $200.8 \pm 2.1 \mathrm{Ba}$ & $111.9 \pm 9.2 \mathrm{Aa}$ & $113.5 \pm 9.9 \mathrm{Aa}$ & $105.9 \pm 9.9 \mathrm{Aa}$ \\
\hline & 12 & $190.9 \pm 1.5 \mathrm{Ab}$ & $180.8 \pm 1.0 \mathrm{Ba}$ & $168.2 \pm 2.5 \mathrm{Bb}$ & $107.4 \pm 8.2 \mathrm{Aa}$ & $95.2 \pm 8.3 \mathrm{Aa}$ & $101.0 \pm 8.4 \mathrm{Aa}$ \\
\hline \multirow[t]{2}{*}{ Hydroxytyrosol-4-Glucose } & 0 & $7.4 \pm 0.1 \mathrm{Aa}$ & $6.2 \pm 0.2 \mathrm{Ba}$ & $6.8 \pm 0.1 \mathrm{Ba}$ & $10.2 \pm 0.1 \mathrm{Aa}$ & $10.6 \pm 0.2 \mathrm{Aa}$ & $9.6 \pm 0.1 \mathrm{Ba}$ \\
\hline & 12 & $6.6 \pm 0.3 \mathrm{Aa}$ & $6.3 \pm 0.2 \mathrm{Ba}$ & $5.6 \pm 0.7 \mathrm{Ba}$ & $10.0 \pm 0.1 \mathrm{Aa}$ & $9.0 \pm 0.1 \mathrm{Bb}$ & $9.8 \pm 0.1 \mathrm{Aa}$ \\
\hline \multirow[t]{2}{*}{ Tyrosol } & 0 & $32.9 \pm 2.4 \mathrm{Aa}$ & $28.5 \pm 1.2 \mathrm{Ba}$ & $30.1 \pm 0.8 \mathrm{Ba}$ & $9.8 \pm 0.3 \mathrm{Aa}$ & $9.9 \pm 0.2 \mathrm{Aa}$ & $9.6 \pm 0.8 \mathrm{Aa}$ \\
\hline & 12 & $31.1 \pm 1.5 \mathrm{Aa}$ & $28.5 \pm 1.2 \mathrm{Ba}$ & $26.2 \pm 0.9 \mathrm{Bb}$ & $10.5 \pm 0.6 \mathrm{Ba}$ & $9.1 \pm 0.7 \mathrm{Aa}$ & $9.8 \pm 0.9 \mathrm{Aa}$ \\
\hline \multirow[t]{2}{*}{ Total phenols } & 0 & $271.0 \pm 4.8 \mathrm{Aa}$ & $229.4 \pm 5.7 \mathrm{Ca}$ & $246.6 \pm 3.3 \mathrm{Ba}$ & $138.4 \pm 9.2 \mathrm{Aa}$ & $140.6 \pm 9.8 \mathrm{Aa}$ & $131.2 \pm 10.7 \mathrm{Aa}$ \\
\hline & 12 & $233.6 \pm 3.8 \mathrm{Ab}$ & $220.1 \pm 2.2 \mathrm{Ba}$ & $204.5 \pm 3.4 \mathrm{Cb}$ & $130.4 \pm 9.1 \mathrm{Aa}$ & $115.2 \pm 8.6 \mathrm{Ba}$ & $123.2 \pm 9.1 \mathrm{Aa}$ \\
\hline
\end{tabular}

Tested solutions were from Spanish style green olive processing, from the 'Manzanilla' and 'Hojiblanca' cultivars. The concentrated solutions were analyzed at 0 and 12 months of storage at room temperature. Values are mean \pm standard deviation

${ }^{a}$ Number followed by the different lowercase letters indicate significant differences according to the LSD test $(p<0.05)$ between data from 0 and 12 months, for the same concentration degree in each compound and cultivar. Number followed by the different uppercase letters indicate significant differences according to the LSD test $(p<0.05)$ for different treatment analyzed at the same time in each compound and cultivar

of the phenolic compounds oxidized under these conditions regardless their type. As reported for the 10 times concentration, 13 times and 17 times were not largely affected by the content of minerals in the concentrates, which is relevant from an agronomic point of view (data not shown).

It must be highlighted that, after 12 months of storage, none of these concentrates showed visible signs of microbial growth, off-odors or gas formation. However, a precipitate was detected at a higher degree of concentration; more significant in the Manzanilla concentrates, which may be related to the lower content in sugars and phenolic compounds found in them (Table 2). These results are in agreement with the loss of $8 \%$ of phenolic compounds in some olive extract rich in hydroxytyrosol after 3 months of storage at room temperature [29].

After 12 months of storage at room temperature, none of these concentrates inhibited the growth of $M$. phaseolina or $B$. cinerea. The solutions concentrated up to 13 times had an inhibitory activity against the growth of $F$. solani when applied at $50 \%$ (Fig. 3a, b), regardless of the cultivar ('Manzanilla' or 'Hojiblanca'), and this inhibitory effect increased if the solutions tested were those concentrated up to 17 times.

Moreover, the highest inhibitory activity was identified against Phytophthora sp. (Fig. 3c, d). All the solutions tested had an inhibitory effect on the growth of this Oomycota, said activity being greater at a higher concentration degree of these solutions. Likewise, at the same degree of concentration, the inhibitory effect was greater at lower dilution of the solution. In particular, concentrates of washing waters of 'Manzanilla' (Fig. 3c) were total inhibitors of the growth of this phytopathogen if they were applied at $50 \%$.

These results showed that the activity against non-bacterial pathogens was maintained by increasing the degree of solution concentration, and this activity also remained stable after 12 months of storage at room temperature.

\section{Biofortifying Capacity of Concentrates Tested at 0 and 12 Months of Storage}

It has recently been shown that olive wastewaters can be used in agriculture as biofertilizers added to the irrigation water of different Mediterranean crops [18, 24], but it was necessary to know if these properties could be preserved with time in concentrated solutions.

The first notable issue was the absence of a phytotoxic effect on tomato plants treated with these fresh table olive concentrated solutions, despite researchers having shown that polymers extracted from olive mil wastewaters led to a phytotoxic effect on tomato plants [30]. 


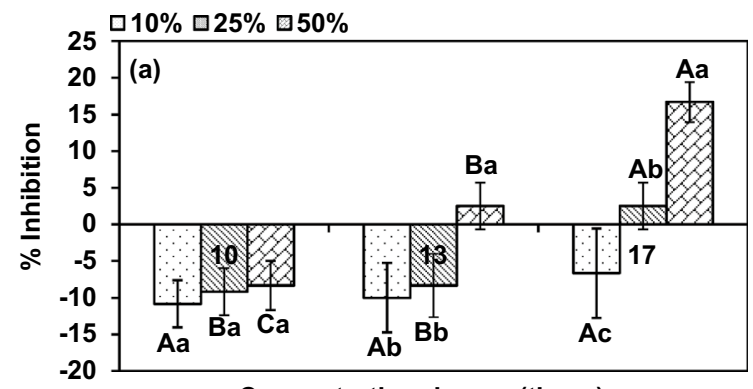

Concentration degree (times)

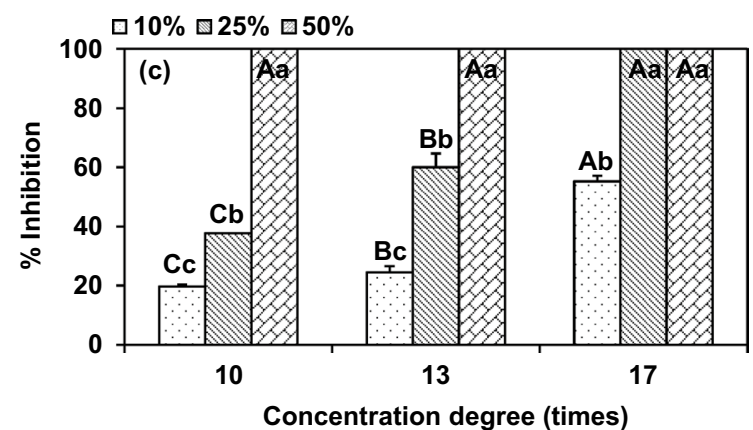

Fig. 3 Mycelial growth inhibition of Fusarium solani (a and $\mathbf{b}$ ) and Phytophthora sp. (c and d), of washing waters of 'Manzanilla' (a and c) and 'Hojiblanca' (b and d) cultivars. The solutions were concentrated at different degrees (10, 13 and 17 times). The concentrates were diluted to the original volume 10, 25 and $50 \%$ and they were tested after 12 months of storage at room temperature. Standard deviation of replicates is depicted in each bar. Bars followed by the

In contrast, the average height of the tomato plants was higher when they were irrigated with concentrated washing waters diluted at $50 \%$ of their non-concentrated volume, than those plants irrigated with only tap water or potassium nitrate solution (Fig. 4). Indeed, a similar effect was found with concentrates stored for 1 year, which confirmed previous data obtained with table olive solutions [26] or extracts rich in hydroxytyrosol [16].

Flowering started about 15-20 days after the application of the first irrigation treatment, and in all cases more than $50 \%$ of plants had at least one flower. After 30 days, no statistically significant difference was observed between the treatments (data not shown).

With respect to the cumulative yield, it was much higher in plants irrigated with most of the solutions tested (potassium nitrate, washing waters of 'Manzanilla' and 'Hojiblanca') than when using only tap water, irrespective of the storage time of the concentrates (Fig. 4). Similar results have been demonstrated when using other wastewaters from food [17, 31]. Regarding the average size of the tomatoes, no statistically significant difference was found between the treatments when the freshly prepared concentrates $(0 \mathrm{~m})$ were applied, although after 1 year of storage
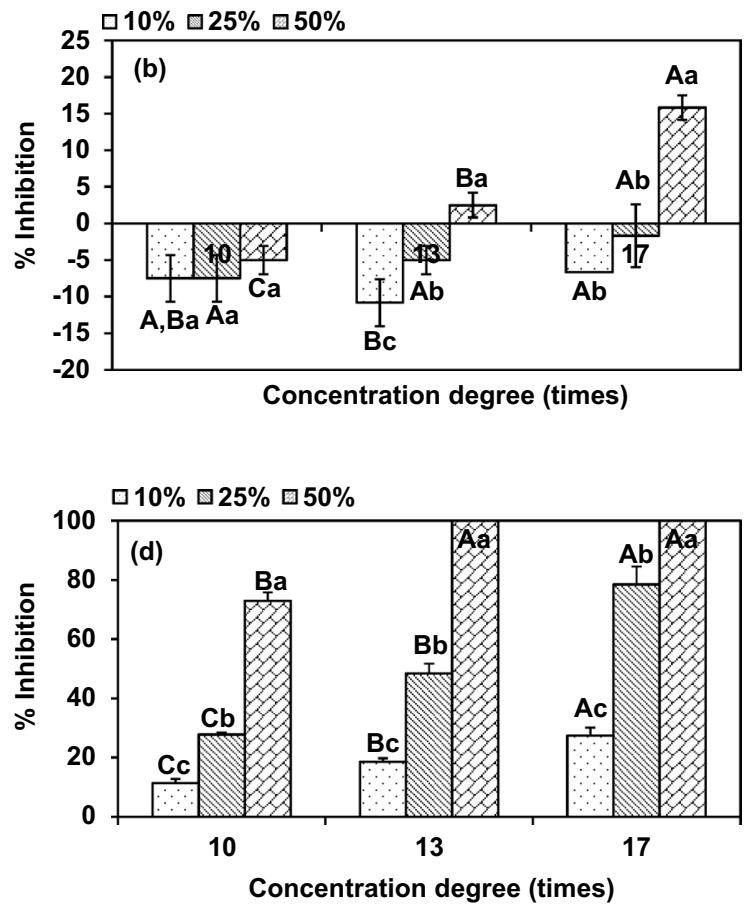

different lowercase letters indicate significant differences according to the LSD test $(p<0.05)$ between data for different dilution, and the same concentration degree in each graph. Bars followed by the different uppercase letters indicate significant differences according to the LSD test $(p<0.05)$ for the same dilution, and different concentration degree in each graph

the fruits irrigated with the concentrates from 'Manzanilla' had bigger calibers.

Overall, concentrates of 'Manzanilla' were more favorable than those of 'Hojiblanca' for plant development and yield. The chemical composition of these concentrates was different, because those from the 'Manzanilla' cultivar had a higher concentration of sugars and phenolic compounds (Table 2) than those from the "Hojiblanca" cultivar. In addition, 'Manzanilla' concentrates had higher percentage of phosphorus (5.2\%) than 'Hojiblanca' concentrates (3.3\%).

Likewise, most of the $\mathrm{pHs}$ were close to the current industrial tomato purees ( $4.3 \mathrm{pH}$ units) without any significant effect due to the use of olive waste strems (Table 3 ). In terms of the sweetness and acidity parameters, the best tomatoes being those treated with fertilizer (potassium nitrate at $50 \%$ ), whose sweetness was $6.27^{\circ}$ Brix and acidity $0.35 \%$ of citric acid, data that indicated high quality tomatoes [32]. Finally, a maturity index of 10 correlates with an excellent sugar/acid combination, and consequently better flavor, and the results of all treatments were higher than this value. 

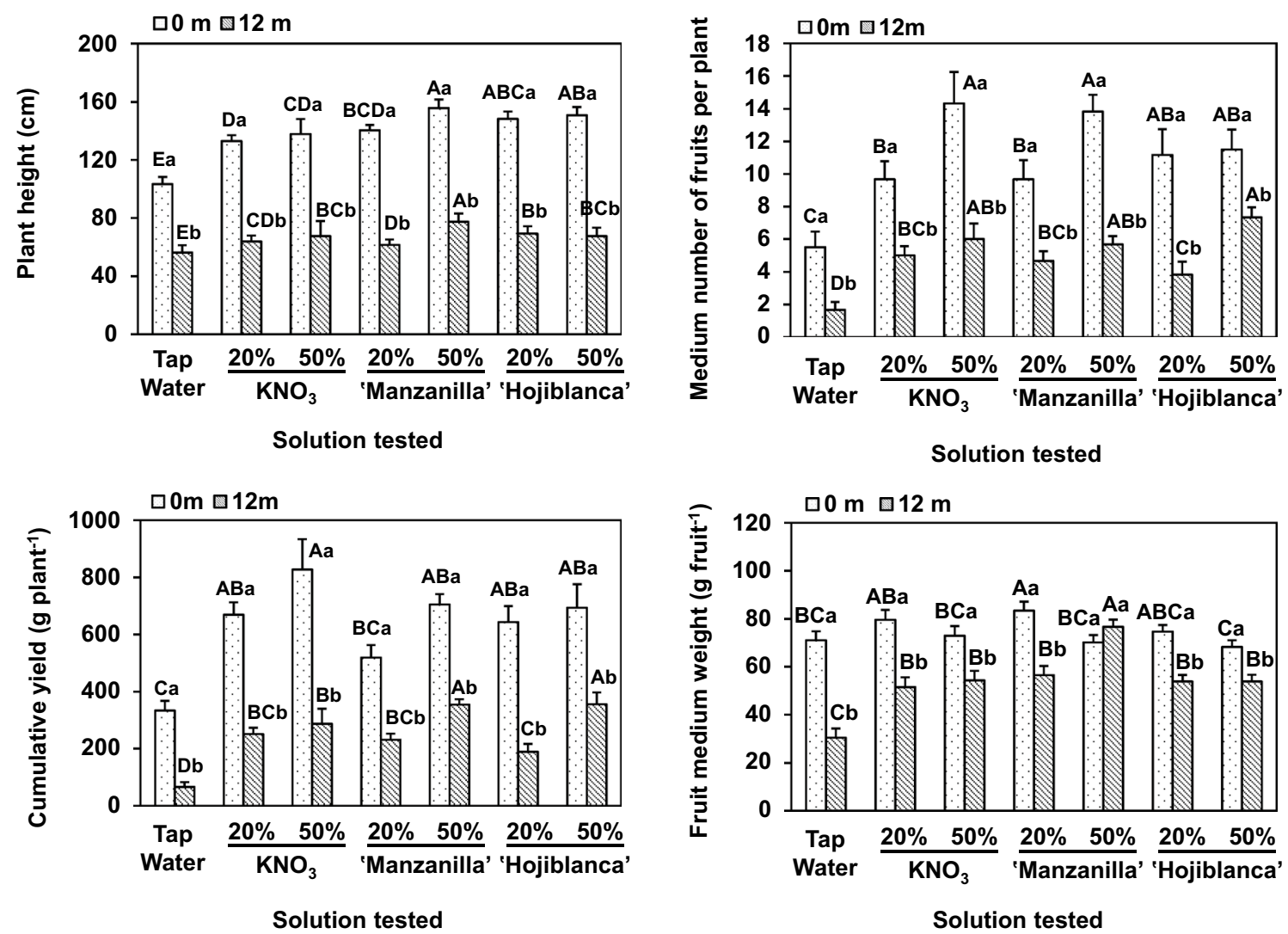

Fig. 4 Plant height, medium number of fruits per plant, cumulative yield and fruit medium weight of tomato cultivar treated with two washing waters from Spanish style green olive processing, from the 'Manzanilla' and 'Hojiblanca' cultivars. Wastewater solutions were concentrated up to 10 times and diluted to the original volume to test them. Two control solutions were used: water and potassium nitrate $\left(\mathrm{KNO}_{3}\right)$. The solutions were diluted 1:4 $(20 \%)$ or $1: 1(50 \%)$ with tap water and applied by irrigation. The concentrated solutions were

\section{Conclusions}

The results obtained in this study revealed that washing waters from Spanish style green and storage liquids from black ripe olives, can be vacuum concentrated up to 17 times without losing sugars, minerals and most of the phenolic compounds. Besides, these concentrates were chemically and microbiologically stable for 12 months, preserving their antimicrobial activity against the bacteria $E$. amylovora and

tested at 0 and 12 months of storage at room temperature. Standard deviation of ten replicates is depicted in each bar. Bars followed by the different lowercase letters indicate significant differences according to the LSD test $(p<0.05)$ between data from 0 and 12 months for the same treatment tested in each graph. Bars followed by the different uppercase letters indicate significant differences according to the LSD test $(p<0.05)$ for different treatment tested at the same time in each graph

$P$. syringae, and the phytopathogens $F$. solani and Phytophthora sp.

In addition, this study confirmed the biofertilizing effect of these concentrated solutions on tomato plant grown in pots within controlled greenhouses. This effect was maintained even after concentrates were stored for 12 months. Yet the results have been so promising, that they have encouraged us to continue future research regarding the application of these solutions, as part of irrigation water in field trials with different Mediterranean crops. 
Table $3 \mathrm{pH}$, sweetness, acidity and maturity index of the tomato puree obtained from fruits treated with two washing waters from Spanish style green olive processing of the 'Manzanilla' (Mz) and 'Hojiblanca' $(\mathrm{Hj})$ cultivars

\begin{tabular}{lrllll}
\hline Treatment & Time $^{\mathrm{a}}(\mathrm{m})$ & $\mathrm{pH}$ & Sweetness $\left({ }^{\circ} \mathrm{Brix}\right)$ & Acidity $(\%$ citric acid $)$ & Maturity Index \\
\hline Tap water & 0 & $4.38 \pm 0.02 \mathrm{Aa}$ & $5.66 \pm 0.12 \mathrm{BCa}$ & $0.24 \pm 0.01 \mathrm{Ca}$ & $23.9 \pm 1.0 \mathrm{Aa}$ \\
& 12 & $4.19 \pm 0.03 \mathrm{Cb}$ & $5.11 \pm 0.17 \mathrm{Db}$ & $0.25 \pm 0.02 \mathrm{BCa}$ & $15.8 \pm 1.0 \mathrm{Ab}$ \\
$\mathrm{KNO}_{3}-20 \%$ & 0 & $4.39 \pm 0.02 \mathrm{Aa}$ & $5.39 \pm 0.09 \mathrm{CDa}$ & $0.26 \pm 0.01 \mathrm{BCb}$ & $21.8 \pm 0.8 \mathrm{BCa}$ \\
& 12 & $4.34 \pm 0.03 \mathrm{Aba}$ & $5.36 \pm 0.15 \mathrm{BCa}$ & $0.29 \pm 0.02 \mathrm{BCa}$ & $18.9 \pm 0.8 \mathrm{Ab}$ \\
$\mathrm{KNO}_{3}-50 \%$ & 0 & $4.35 \pm 0.01 \mathrm{Aa}$ & $6.27 \pm 0.17 \mathrm{Aa}$ & $0.34 \pm 0.02 \mathrm{Ab}$ & $19.1 \pm 0.5 \mathrm{Da}$ \\
& 12 & $4.25 \pm 0.03 \mathrm{Cb}$ & $6.27 \pm 0.15 \mathrm{Aa}$ & $0.39 \pm 0.02 \mathrm{Aa}$ & $16.5 \pm 0.8 \mathrm{Ab}$ \\
$\mathrm{Mz}-20 \%$ & 0 & $4.41 \pm 0.03 \mathrm{Aa}$ & $5.31 \pm 0.10 \mathrm{Da}$ & $0.24 \pm 0.02 \mathrm{Cb}$ & $23.7 \pm 1.1 \mathrm{Aba}$ \\
& 12 & $4.34 \pm 0.03 \mathrm{Aba}$ & $5.22 \pm 0.15 \mathrm{CDa}$ & $0.32 \pm 0.02 \mathrm{Aba}$ & $16.5 \pm 0.8 \mathrm{Ab}$ \\
$\mathrm{Mz}-50 \%$ & 0 & $4.37 \pm 0.08 \mathrm{Aa}$ & $5.74 \pm 0.13 \mathrm{Ba}$ & $0.29 \pm 0.01 \mathrm{Ba}$ & $20.3 \pm 0.5 \mathrm{CDa}$ \\
& 12 & $4.37 \pm 0.03 \mathrm{Aa}$ & $5.38 \pm 0.15 \mathrm{BCa}$ & $0.31 \pm 0.02 \mathrm{Aba}$ & $17.3 \pm 0.8 \mathrm{Ab}$ \\
$\mathrm{Hj}-20 \%$ & 0 & $4.39 \pm 0.03 \mathrm{Aa}$ & $5.39 \pm 0.11 \mathrm{CDb}$ & $0.24 \pm 0.01 \mathrm{Cb}$ & $23.1 \pm 0.6 \mathrm{Aba}$ \\
& 12 & $4.30 \pm 0.04 \mathrm{ABCb}$ & $5.77 \pm 0.18 \mathrm{Aba}$ & $0.29 \pm 0.02 \mathrm{BCa}$ & $18.8 \pm 1.0 \mathrm{Ab}$ \\
$\mathrm{Hj}-50 \%$ & 0 & $4.36 \pm 0.02 \mathrm{Aa}$ & $5.63 \pm 0.09 \mathrm{BCDa}$ & $0.28 \pm 0.01 \mathrm{Bb}$ & $20.0 \pm 0.5 \mathrm{CDa}$ \\
& 12 & $4.27 \pm 0.03 \mathrm{BCb}$ & $5.11 \pm 0.15 \mathrm{CDb}$ & $0.39 \pm 0.02 \mathrm{Aa}$ & $15.8 \pm 0.8 \mathrm{Ab}$ \\
\hline
\end{tabular}

Washing waters were concentrated up to 10 times and diluted to the original volume to test them. Two control solutions were used, water and potassium nitrate $\left(\mathrm{KNO}_{3}\right)$. The solutions were diluted 1:4 $(20 \%)$ or 1:1 $(50 \%)$ with tap water and applied by irrigation. Values are mean \pm standard error of ten replicates

${ }^{\text {a }}$ The concentrated solutions were tested at 0 and 12 months of storage at room temperature. Column values followed by the different lowercase letters indicate significant differences according to the LSD test $(p<0.05)$ between data from 0 and 12 months for the same treatment tested. Column values followed by the different uppercase letters indicate significant differences according to the LSD test
Acknowledgements We thank Alejandra Expósito for the technical assistance.

Author Contributions Conceptualization: CR, MB; Methodology: CR, MB, BDLS; Formal analysis: CR, BDLS; Investigation: CR, MB, AdC, PG, AA; Writing — original draft preparation—review and editing: CR; Review Draft: MB, AdC, PG, BDLS, AA; Funding acquisition: CR, MB; Supervision: CR, MB, BDLS.

Funding Open Access funding provided thanks to the CRUE-CSIC agreement with Springer Nature. This work was supported by the Junta de Andalucía Government (Project P07-AGR-03105, FEDER, UE) and the Spanish Government (Project AGL2016-76820-R, AEI/FEDER, $\mathrm{UE})$.

Availability of Data and Material The datasets generated during and/or analyzed during the current study are available from the corresponding author on reasonable request.

Code Availability Not applicable.

\section{Declarations}

Conflict of interest On behalf of all authors, the corresponding author states that there is no conflict of interest.

Open Access This article is licensed under a Creative Commons Attribution 4.0 International License, which permits use, sharing, adaptation, distribution and reproduction in any medium or format, as long as you give appropriate credit to the original author(s) and the source, provide a link to the Creative Commons licence, and indicate if changes were made. The images or other third party material in this article are included in the article's Creative Commons licence, unless indicated otherwise in a credit line to the material. If material is not included in the article's Creative Commons licence and your intended use is not permitted by statutory regulation or exceeds the permitted use, you will need to obtain permission directly from the copyright holder. To view a copy of this licence, visit http://creativecommons.org/licenses/by/4.0/.

\section{References}

1. Beltrán, F.J., García-Araya, J.F., Frades, J., Álvarez, P., Gimeno, O.: Effects of single and combined ozonation with hydrogen peroxide or UV radiation on the chemical degradation and biodegradability of debittering table olive industrial wastewaters. Water Res. 33, 723-732 (1999)

2. Benítez, F.J., Acero, J.L., González, T., García, J.: Ozonation and biodegradation processes in batch reactors treating black table olives washing wastewaters. Ind. Eng. Chem. Res. (2001). https:// doi.org/10.1021/ie000735c

3. Benekos, A.K., Zampeta, C., Argyriou, R., Economou, C.N., Triantaphyllidou, I.E., Tatoulis, T.I., Tekerlekopoulou, A.G., Vayenas, D.V.: Treatment of table olive processing wastewaters using electrocoagulation in laboratory and pilot-scale reactors. Process. Saf. Environ. (2019). https://doi.org/10.1016/j.psep.2019.08.036

4. Gargouri, B., Gargouri, O.D., Khmakhem, I., Ammar, S., Abdelhèdi, R., Bouaziz, M.: Chemical composition and direct electrochemical oxidation of table olive processing wastewater using high oxidation power anodes. Chemosphere (2017). https://doi. org/10.1016/j.chemosphere.2016.09.080

5. Tatoulis, T.I., Zapantiotis, S., Frontistis, Z., Akratos, C.S., Tekerlekopoulou, A.G., Pavlou, S., Mantzavinos, D., Vayenas, D.V.: A hybrid system comprising an aerobic biological process and electrochemical oxidation for the treatment of black table olive processing wastewaters. Int. Biodeterior. Biodegrad. (2016). https://doi.org/10.1016/j.ibiod.2016.01.013 
6. Brenes, M., García, P., Romero, C., Garrido, A.: Treatment of green table olive wastewaters by an activated-sludge process. J. Chem. Techno. Biot. (2000). https://doi.org/10.1002/10974660(200006)75:6\%3c459::AID-CTB234\%3e3.0.C.O;2-D

7. Ferrer-Polonio, E., Carbonell-Alcaina, C., Mendoza-Roca, J.A., Iborra-Clar, A., Álvarez-Blanco, S., Bes-Piá, A., PastorAlcaniz, L.: Brine recovery from hypersaline wastewaters from table olive processing by combination of biological treatment and membrane technologies. J. Clean. Prod. (2017). https://doi. org/10.1016/j.jclepro.2016.11.169

8. Brenes, M., García, P., Romero, C., Garrido, A.: Ripe olives storage liquids reuse during the oxidation process. J. Food Sci. (1998). https://doi.org/10.1111/j.1365-2621.1998.tb15689.x

9. Medina, E., García, P., Romero, C., Brenes, M.: Recycling preservation solutions in black ripe olive processing. Int. J. Food Sci. Technol. (2011). https://doi.org/10.1111/j.1365-2621.2011. 02671.x

10. Romero, C., García-Serrano, P., García-García, P., Brenes, M.: Re-use of partially purified iron color fixation solutions using electro-coagulation and ozonation in ripe olive processing and packaging. J. Food Eng. (2016). https://doi.org/10.1016/j.jfood eng.2016.02.020

11. Bouaziz, M., Lassoued, S., Bouallagui, Z., Smaoui, S., Gargoubi, A., Dhouib, A., Sayadi, S.: Synthesis and recovery of high bioactive phenolics from table-olive brine process wastewater. Bioorg. Med. Chem. (2008). https://doi.org/10.1016/j. bmc.2008.09.012

12. Gullón, B., Gullón, P., Eibes, G., Cara, C., De Torres, A., LópezLinares, J.C., Ruiz, E., Castro, E.: Valorisation of olive agroindustrial by-products as a source of bioactive compounds. Sci. Total Environ. (2018). https://doi.org/10.1016/j.scitotenv.2018.07. 155

13. Kiai, H., Raiti, J., El-Abbassi, A., Hafidi, A.: Recovery of phenolic compounds from table olive processing wastewaters using cloud point extraction method. J. Environ. Chem. Eng. (2018). https:// doi.org/10.1016/j.jece.2018.05.007

14. Brenes, M., García, A., De los Santos, B., Medina, E., Romero, C., de Castro, A., Romero, F.: Olive glutaraldehyde-like compounds against plant pathogenic bacteria and fungi. Food Chem. 125, 1262-1266 (2011). https://doi.org/10.1016/j.foodchem.2010.10. 055

15. Capasso, R., Evidente, A., Schivo, L., Orru, G., Marcialis, M.A., Cristinzio, G.: Antibacterial polyphenols from olive oil mill waste-waters. J. Appl. Bacteriol. (1995). https://doi.org/10.1111/j. 1365-2672.1995.tb03153.x

16. Yangui, T., Dhouib, A., Rhouma, A., Sayadi, S.: Potential of hydroxytyrosol-rich composition from olive mill wastewater as a natural disinfectant and its effect on seeds vigour response. Food Chem. (2009). https://doi.org/10.1016/j.foodchem.2009.03.069

17. Chehade, L.A., Al Chami, Z., De Pascali, S.A., Cavoski, I., Fanizzi, F.P.: Biostimulants from food processing by-products: agronomic, quality and metabolic impacts on organic tomato (Solanum lycopersicum L.). J. Sci. Food Agric. (2018). https:// doi.org/10.1002/jsfa.8610

18. De los Santos, B., Brenes, M., García, P., Aguado, A., Medina, E., Romero, C.: Effect of table olive wastewaters on growth and yield of cucumber, pepper, tomato and strawberry. Sci. Hortic. (2019). https://doi.org/10.1016/j.scienta.2019.108644
19. García-Serrano, P., Romero, C., García-García, P., Brenes, M.: Influence of the type of alkali on the processing of black ripe olives. LWT-Food Sci. Technol. (2020). https://doi.org/10.1016/j. lwt.2020.109318

20. García-Serrano, P., Sánchez, A.H., Romero, C., García-García, P., de Castro, A., Brenes, M.: Processing of table olives with $\mathrm{KOH}$ and characterization of the wastewaters as potential fertilizer. Sci. Total Environ. (2019). https://doi.org/10.1016/j.scitotenv.2019.04. 193

21. Medina, E., Brenes, M., Romero, C., García, A., de Castro, A.: Main antimicrobial compounds in table olives. J. Agric. Food Chem. (2007). https://doi.org/10.1021/jf0719757

22. Kato, K., Yoshimoto, M., Shirai, Y.: Systemization of determination methods of major components in sludge fertilizer, compost and organic fertilizer. Res. Rep. Fertil. 3, 107-116 (2010)

23. Pandey, D.K., Tripathi, N.N., Tripathi, R.D., Dixit, S.N.: Fungitoxic and phytotoxic properties of the essential oil of Hyptis suaveolens. Zeitschrift für Pflanzenkrankheiten und Pflantenschutz 89, 344-349 (1982)

24. De los Santos, B., Medina, E., Brenes, M., Aguado, A., García, P., Romero, C.: Chemical composition of table olive wastewater and its relationship with the bio-fortifying capacity of tomato (Solanum lycopersicum L.) plants. Agric. Water Manag. (2020). https:// doi.org/10.1016/j.agwat.2019.105833

25. Sønsteby, A., Heide, O.M.: Long-day control of flowering in everbearing strawberries. J. Hortic. Sci. Biotechnol. (2007). https:// doi.org/10.1080/14620316.2007.11512321

26. Romero, C., Medina, E., de Castro, A., Brenes, M., De los Santos, B., Romero, F.: Procedimiento para la obtención de una solución favorecedora del crecimiento de plantas a partir de aguas de lavado del proceso de elaboración de aceitunas verdes estilo español y uso de dicha solución. Oficina Española de Patentes y Marcas, Número de publicación: 2408134 B1, 1-5 (2014)

27. Dehmani, Y., Ed-Dra, A., Zennouhi, O., Bouymajane, A., Filali, F.R., Nassiri, L., Abouarnadasse, S.: Chemical characterization and adsorption of oil mill wastewater on Moroccan clay in order to be used in the agricultural field. Heliyon (2020). https://doi.org/ 10.1016/j.heliyon.2020.e03164

28. Capasso, R., De Martino, A., Arienzo, M.: Recovery and characterization of the metal polymeric organic fraction (Polymerin) from olive oil mill wastewaters. J. Agric. Food Chem. (2002). https://doi.org/10.1021/jf011442c

29. He, J., Alister-Briggs, M., De Lyster, T., Jones, G.P.: Stability and antioxidant potential of purified olive mill wastewater extracts. Food Chem. (2012). https://doi.org/10.1016/j.foodchem.2011.09. 124

30. Capasso, R., De Martino, A., Cristinzio, G.: Production, characterization, and effects on tomato of humic acid-like polymerin metal derivatives from olive oil mill waste waters. J. Agric. Food Chem. (2002). https://doi.org/10.1021/jf011678g

31. Mekki, A., Arous, F., Aloui, F., Sayadi, S.: Treatment and valorization of agro-wastes as biofertilizers. Waste Biomass Valoriz. (2017). https://doi.org/10.1007/s12649-016-9620-3

32. RAEA (2009) In: de Andalucía, Junta (ed.) Red Andaluza de Experimentación Agraria. Tomate de Industria. Campaña 2008. IFAPA.

Publisher's Note Springer Nature remains neutral with regard to jurisdictional claims in published maps and institutional affiliations. 